\title{
Enhancing productivity of late sown wheat with hydro-priming
}

\author{
Shazma Anwar ${ }^{1}$, Murtaza Amin ${ }^{1}$, Beena Saeed ${ }^{2}$, Shehryar Khan ${ }^{1}$, \\ Muhammad Owais Khan ${ }^{3}$, Shaheen Kashmir ${ }^{4}$ and Muhammad Islam ${ }^{1 *}$ \\ 1. Department of Agronomy, The University of Agriculture, Peshawar-Pakistan \\ 2. Department of Agriculture, University of Sawabi, Sawabi-Pakistan \\ 3. Department of Soil \& Environmental Sciences, The University of Agriculture, Peshawar-Pakistan \\ 4. Department of Botany, The University of Agriculture, Peshawar-Pakistan \\ *Corresponding author's email: islamswati439@yahoo.com \\ Citation \\ Shazma Anwar, Murtaza Amin, Beena Saeed, Shehryar Khan, Muhammad Owais Khan, Shaheen Kashmir and \\ Muhammad Islam. Enhancing productivity of late sown wheat with hydro-priming. Pure and Applied Biology. \\ Vol. 7, Issue 4, 1339-1345. http://dx.doi.org/10.19045/bspab.2018.700156

\begin{tabular}{llll}
\hline \hline Received: 17/04/2018 & Revised: 13/09/2018 & Accepted: 29/09/2018 & Online First: 04/10/2018 \\
\hline
\end{tabular}

\section{Abstract}

A field trial was carried out to investigate the effect of seed priming on the productivity of late sown wheat during fall-2016. The experiment was laid out in randomized complete block design (RCBD) with split-plot arrangement having three replications. Two factors (sowing dates and priming) were tested in the experiment. Sowing dates $\left(29^{\text {th }}\right.$ Oct, $10^{\text {th }}$ Nov, $24^{\text {th }}$ Nov, $10^{\text {th }}$ Dec, $26^{\text {th }}$ Dec and $10^{\text {th }}$ Jan) were assigned to main plots, while priming (non-primed and primed) was allotted to sub-plots. Wheat variety "SIRAN-2010" was sown in a plot size of $1.8 \mathrm{~m} \times 5 \mathrm{~m}$. Results showed that wheat crop sown on $29^{\text {th }}$ Oct resulted in early emergence (6 days), increased emergence $\mathrm{m}^{-2}(139)$ plant height $(101.61 \mathrm{~cm})$, spikes $\mathrm{m}^{-2}(280)$, grains spike ${ }^{-1}$ (46.63), thousand grain weight (44g), biological yield (9770 kg ha-1) and grain yield (4038 kg $\left.\mathrm{ha}^{-1}\right)$. Late sown wheat in $\left(10^{\text {th }} \mathrm{Jan}\right)$ took lesser days (136) to maturity. In case of seed priming early emergence (11 days), more emergence $\mathrm{m}^{-2}(102)$, taller plants $(85.19 \mathrm{~cm})$, more spikes $\mathrm{m}^{-}$ ${ }^{2}(216)$, higher grains spike $^{-1}(40.18)$, maximum 1000 -grains weight $(37 \mathrm{~g})$, maximum grain yield (3116 $\left.\mathrm{kg} \mathrm{ha}^{-1}\right)$ and maximum biological yield $\left(7630 \mathrm{~kg} \mathrm{ha}^{-1}\right)$ was recorded in plots sown with hydro-primed seed. However, dry sown seed took more days (163) to emergence. Hence it is concluded that sowing from $29^{\text {th }}$ Oct to $10^{\text {th }}$ Nov significantly increased yield and yield related components of wheat. Similarly seed priming is necessary for higher yield of late sown wheat.

Keywords: Hydro-priming; Wheat; Sowing dates

\section{Introduction}

Wheat (Triticum aestivum L.) is an annual self-pollinated, long day cereal crop. It is a staple food and high value crop containing approximately $11-15 \%$ protein, $60-70 \%$ carbohydrates and traces of minerals [1]. In Pakistan, wheat is grown on $68 \%$ of the total cropped area and is the major food item that fulfills $95 \%$ of the food requirements of the whole country [2]. It is mostly grown in the northern hemisphere; North America, Europe, China and Russia, which account for more than $80 \%$ of the world wheat supply [3]. The per capita wheat consumption is $125 \mathrm{~kg}_{\text {year }}{ }^{-1}$, which is among the highest in the world. In Pakistan, area under wheat cultivation was 8.64 million hectares and production was 23.47 million tones with an average yield of $2714 \mathrm{~kg} \mathrm{ha}^{-1}$. In Khyber Pakhtunkhwa total area under wheat cultivation was 0.729 million hectares while its production was 1.13 million tones and average yield was $1550 \mathrm{~kg} \mathrm{ha}^{-1}$ [4]. 
Sowing date is one of the important factors which directly affect growth and grain yield of wheat. Flowering, maturity, seed filling duration, seed weight and grains spike ${ }^{-1}$ are significantly affected by time of sowing. Too early sowing may utilize soil moisture accumulated in the fall. However, medium season seeding of winter wheat for any locality is usually favorable [5]. Grain yield declined with delaying sowing with a loss of $200-250 \mathrm{~kg}$ grain $\mathrm{ha}^{-1}$ for each week's delay in sowing time [6]. Delayed sowing decreased grain yield due to decrease in germination count $\mathrm{m}^{-2}$, number of grains spike $^{-1}$ and thousand grains weight whereas increase in seed rate did not affect grain yield [7]. Wheat yield $\mathrm{ha}^{-1}$ in Pakistan is very low as compared to others countries where the yield $\mathrm{ha}^{-1}$ is three times more and almost double in china [4] the causes could be low germination and poor stand establishment.

In Khyber Pakhtunkhwa more than $60 \%$ of the wheat is cultivated on rain-fed land. Seed priming improves percentage and time to germination and it is more successful in wheat $[8,9]$. Seed priming benefits wheat germination under mild drought stress [10]. Wheat cv. Inqilab and S-24 when soaked in water sustained salinity [11] and germinate earlier than dry seed [12]. Seed priming improves the vigor and uniformity of germination [13]. For wheat seed priming with water is also used as a best medium [14]. Keeping in view the importance of suitable sowing time and seed priming the current experiment was carried out to investigate the effect of seed priming on the productivity of late sown wheat.

\section{Materials and methods}

The effect of hydro-priming on late sown wheat was tested at the Agronomy Research Farm, The University of Agriculture Peshawar-Pakistan during fall 2016-17. Two factorial experiment (sowing dates and seed priming with water) was carried out in a randomized complete block design (RCBD) with split-plot arrangement. Sowing dates $\left(29^{\text {th }}\right.$ October, $10^{\text {th }}$ November, $24^{\text {th }}$ November, $10^{\text {th }}$ December, $26^{\text {th }}$ December and $10^{\text {th }}$ January) were allotted to main plots, whereas seed priming (dry seed and water soaked seed) were allotted to sub plots. A sub plot of size $5 \mathrm{~m} \times 1.8 \mathrm{~m}$ (with 6 rows $30 \mathrm{~cm}$ apart) was used. Seed of wheat variety "SIRAN-2010" were soaked in water for six hours at room temperature and sown@150 kg ha ${ }^{-1}$. All other agronomic practices were uniformly maintained for all the experimental units. Data ware recorded on days to emergence, emergence $\mathrm{m}^{-2}$, plant height, days to physiological maturity, spikes $\mathrm{m}^{-2}$, grains spike ${ }^{-1}$, 1000-grains weight, biological yield and grain yield following the desirable standard procedure. Method applicable to the randomized complete block design (split-plot arrangement) was used for statistical analysis of the recorded data. For mean comparison in case of significant difference least significant difference (LSD) test at 5\% level of significance was used [15].

\section{Results and discussion}

\section{Days to emergence}

Sowing dates and seed priming significantly affected days to emergence of wheat (Table 1). More days to emergence (16 days) were taken by late sown pltant ( $10^{\text {th }}$ January), while wheat crop sown on $29^{\text {th }}$ October took lesser days to emergence (6 days). Increase in days to emergence with delay in sowing may be due to drop in temperature. Seed priming also showed a significant effect on days to emergence of wheat. More days to emergence (12 days) were taken by dry sown seeds (non-primed) as compared to seed primed with water which took less days (11). Similar results were also reported by [16] who found early emergence of wheat seed primed with distilled water and saturated gunny bags.

\section{Emergence $\mathbf{~ m}^{-2}$}

Table 1 showed that sowing dates and seed priming significantly affected emergence $\mathrm{m}^{-2}$ of wheat. Interaction between sowing dates and hydro priming was found nonsignificant. Maximum emergence $\mathrm{m}^{-2}$ (139) was observed in plots sown on $10^{\text {th }}$ 
November, while late sowing ( $10^{\text {th }}$ January) gave minimum emergence $\mathrm{m}^{-2}$ (20). These results are in conformity with [17] who stated that different sowing dates had significant effect on germination. Delayed sowing for all varieties of wheat had negative effect on emergence per unit area [18]. In case of seed priming, less emergence $\mathrm{m}^{-2}$ (94) was recorded in plots sown with non-primed seed, while more emergence $\mathrm{m}^{-2}$ (102) was recorded in plots sown with hydro-primed seed. The enhanced emergence in primed seed improved the stand of wheat crop, emergence $\mathrm{m}^{-2}$ and accelerated the chemical reactions in seed which are essential for emergence of seed [19].

\section{Plant height (cm)}

Plant height considerably varied by sowing dates and seed priming while their interaction was found non-significant (Table 1). Plant height significantly decreased $(49.50 \mathrm{~cm})$ in delayed sowing $\left(10^{\text {th }} \mathrm{Jan}\right)$, whereas taller plants $(101.61 \mathrm{~cm})$ were observed in plot sown on $29^{\text {th }}$ October. These results are in agreement with [20] who stated that plant height decreased significantly as planting was delayed from mid-November to December. Taller plants $(85.19 \mathrm{~cm})$ were recorded by hydropriming, while non-primed seed produced dwarf plants $(83.20 \mathrm{~cm})$. Similar results were reported [21] who found taller plants in plots having seeds treated with phosphorous solution.

\section{Days to physiological maturity}

A significant effect of sowing dates on days to physiological maturity of wheat is presented in (Table 2). Seed priming and the interaction between sowing dates and priming was found non-significant. Delayed maturity (187 days) was observed in plots sown on $29^{\text {th }}$ October, while early maturity (133 days) was noticed in plots sown on $10^{\text {th }}$ January. Delaying sowing plants had less vegetative period due to long day nature of wheat crop and enter into reproductive stage earlier and thereby took fewer days to maturity. The results are in agreement with findings of [22], who reported that delay in sowing hastened physiological maturity.

Table 1. Days to emergence, emergence $\mathrm{m}^{-2}$ and plant height of wheat as affected by sowing dates and priming

\begin{tabular}{|c|c|c|c|}
\hline Treatments & Days to emergence & Emergence $\mathbf{m}^{-2}$ & Plant height (cm) \\
\hline \multicolumn{4}{|c|}{ Sowing Dates (SD) } \\
\hline 29-Oct & $6 f$ & $124 \mathrm{~b}$ & $101.61 \mathrm{a}$ \\
\hline 10-Nov & $7 \mathrm{e}$ & $139 a$ & $99.61 \mathrm{a}$ \\
\hline 24-Nov & $9 \mathrm{~d}$ & $125 b$ & $98.83 \mathrm{a}$ \\
\hline 10-Dec & $12 \mathrm{c}$ & $111 \mathrm{c}$ & $91.67 \mathrm{~b}$ \\
\hline 26-Dec & $14 \mathrm{~b}$ & $70 \mathrm{~d}$ & $63.94 \mathrm{c}$ \\
\hline 10-Jan & $16 \mathrm{a}$ & $20 \mathrm{e}$ & $49.50 \mathrm{~d}$ \\
\hline LSD value & 1.18 & 15.56 & 4.5 \\
\hline \multicolumn{4}{|c|}{ Priming $(\mathbf{P})$} \\
\hline Dry seed & $12 \mathrm{a}$ & $94 \mathrm{~b}$ & $83.20 \mathrm{~b}$ \\
\hline Water soaked seed & $11 \mathrm{~b}$ & $102 a$ & $85.19 \mathrm{a}$ \\
\hline LSD value & 0.29 & 3.43 & 1.09 \\
\hline \multicolumn{4}{|c|}{ LSD values for interaction } \\
\hline SD x P & NS & NS & NS \\
\hline
\end{tabular}

Means with different letters differ significantly according to Least Significant Difference (LSD) test $(P<0.05)$. NS stands for non-significant difference

\section{Spikes $\mathbf{m}^{-2}$}

It is evident that sowing dates and seed priming significantly affected spikes $\mathrm{m}^{-2}$ of wheat (Table 2). In case of sowing dates more number of spike $\mathrm{m}^{-2}$ (280) were observed in $29^{\text {th }}$ October sown plots, while 
less number of spikes $\mathrm{m}^{-2}$ (50) were observed in plots sown on $10^{\text {th }}$ January. These results are in agreement with [23] who reported that number of spikes per unit area reduced in earlier and late planted plots of wheat than normal sowing date. Similarly, greater no of spikes $\mathrm{m}^{-2}(216)$ was observed for water soaked seed as compared to dry seed which produced 207 spikes $\mathrm{m}^{-2}$. Similar results were observed by [11] who stated that increase in spikes $\mathrm{m}^{-2}$ due to priming might be due to improved emergence and better seedling growth. The interaction of sowing dates and priming stayed not significant.

Grains spike ${ }^{-1}$

A significant variation in number of grains spike $^{-1}$ of wheat by sowing dates and seed priming is presented in (Table 2). Maximum grains spike $^{-1}$ (46.63) were counted in plots sown on $29^{\text {th }}$ October, minimum grains spike $^{-1}$ (17.88) were recorded in last sowing ( $10^{\text {th }}$ January). These results are in agreement with $[24,25$, 26], who concluded that grains spike ${ }^{-1}$ significantly decreased with delay in sowing. In case of seed priming more grains spike $^{-1}$ (40.18) were produced by water soaked seeds and less number of grains $\operatorname{spike}^{-1}$ (39.33) were produced by dry sown seed. Our results are in line with the findings of $[16,27]$ who reported that in mung bean grains pod $^{-1}$ enhanced by treated seeds.

Table 2. Spikes $\mathbf{m}^{-2}$, grains spike ${ }^{-1}$ and days to physiological maturity of wheat as affected by sowing dates and priming

\begin{tabular}{|c|c|c|c|}
\hline Treatments & Spikes $\mathbf{m}^{-2}$ & Grain spike $^{-1}$ & Days to physiological maturity \\
\hline \multicolumn{4}{|c|}{ Sowing Dates (SD) } \\
\hline 29-Oct & $280 \mathrm{a}$ & $46.63 \mathrm{a}$ & $187 \mathrm{a}$ \\
\hline 10-Nov & $266 a b$ & $46.10 \mathrm{ab}$ & $183 \mathrm{~b}$ \\
\hline 24-Nov & $226 b c$ & $45.03 \mathrm{bc}$ & $163 \mathrm{c}$ \\
\hline 10-Dec & $245 \mathrm{c}$ & $44.02 \mathrm{c}$ & $154 d$ \\
\hline 26-Dec & 200d & $38.86 \mathrm{~d}$ & $151 d$ \\
\hline 10-Jan & $50 \mathrm{e}$ & $17.88 \mathrm{e}$ & $136 \mathrm{e}$ \\
\hline LSD value & 32.23 & 1.4 & 4.65 \\
\hline \multicolumn{4}{|c|}{ Priming (P) } \\
\hline Dry seed & $207 \mathrm{~b}$ & $29.33 b$ & 163 \\
\hline Water soaked seed & $216 \mathrm{a}$ & $40.18 \mathrm{a}$ & 161 \\
\hline LSD value & 3.57 & 0.42 & NS \\
\hline \multicolumn{4}{|c|}{ LSD values for interaction } \\
\hline $\mathrm{SD} \times \mathrm{P}$ & NS & NS & NS \\
\hline
\end{tabular}

Means with different letters differ significantly according to Least Significant Difference (LSD) test $(P<0.05)$. NS stands for non-significant difference

\section{Thousand grains weight $(\mathrm{g})$}

It is revealed from statistical analysis of the data that 1000-garins weight of wheat varied considerably by both sowing dates and seed priming (Table 3). Higher thousand grains weight $(44 \mathrm{~g})$ was recorded in plots sown on $29^{\text {th }}$ October, while the lower thousand grains weight $(22 \mathrm{~g})$ was recorded in late sown plots ( $10^{\text {th }}$ January). Decrease in grains weight with delay in sowing might be due to short growth period, where grains did not develop properly and hence resulted in low weight. The results are in conformity with [23] who reported that thousand grains weight significantly decrease with delay in sowing date. Similarly, maximum thousand grains weight $(37 \mathrm{~g})$ was recorded in case of primed seed, while minimum 1000-grains weight $(36 \mathrm{~g})$ was recorded by non-primed seed. Similar results were found by [16] 
who stated that seed priming increased grains weight and biomass.

Grain yield (kg ha-1)

A significant variation in grain yield of wheat was observed with different sowing dates and seed hydro-priming, while their interaction was found non-significant (Table 3). Early sown plants (29 $9^{\text {th }}$ October) produced maximum grain yield $(4038 \mathrm{~kg}$ $\mathrm{ha}^{-1}$ ), whereas minimum grain yield (1065 $\mathrm{kg} \mathrm{ha}^{-1}$ ) was recorded in plots sown late $\left(10^{\text {th }}\right.$ January). A significant decrease in grain yield was also found by [28]. Likewise water soaked seed gave maximum grain yield $\left(3116 \mathrm{~kg} \mathrm{ha}^{-1}\right)$ than that of dry sown seed which produced minimum yield $\left(2779 \mathrm{~kg} \mathrm{ha}^{-1}\right)$. Our results are in conformity with the investigation of [29] who found significant increase in grain yield of wheat when seed was primed different agents (PEG, $\mathrm{Na}_{2} \mathrm{SO}_{4}, \mathrm{KNO}_{3}$ and hydro-priming).

\section{Biological yield $\left(\mathrm{kg} \mathrm{ha}^{-1}\right)$}

Sowing dates and seed priming significantly affected biological yield of wheat (Table 3). Higher biological yield $\left(9770 \mathrm{~kg} \mathrm{ha}^{-1}\right)$ was recorded in plots sown on $29^{\text {th }}$ October, while lower biological yield (3200 kg ha-1) was produced by the plots sown on $10^{\text {th }}$ January.

In case seed priming minimum biological yield (6983 kg ha-1) was obtained from dry seed (non-primed), whereas water primed seed gave maximum biological yield (7630 $\mathrm{kg} \mathrm{ha}{ }^{-1}$ ). Similar results were noticed by [28], who observed significant increase in biological yield by seed priming.

Table 3. Thousand grain weight, grain yield and biological yield of wheat as affected by sowing dates and priming

\begin{tabular}{|c|c|c|c|}
\hline Treatments & $\begin{array}{c}\text { Thousand grains } \\
\text { weight (g) }\end{array}$ & $\begin{array}{c}\text { Grain yield } \\
\left(\mathrm{kg} \mathrm{ha}^{-1}\right)\end{array}$ & $\begin{array}{c}\text { Biological yield } \\
\left(\mathrm{kg} \mathrm{ha}^{-1}\right)\end{array}$ \\
\hline \multicolumn{4}{|c|}{ Sowing Dates (SD) } \\
\hline 29-Oct & $44 a$ & $4038 \mathrm{a}$ & $9770 \mathrm{a}$ \\
\hline 10-Nov & $42 b$ & $3984 a$ & $9432 a$ \\
\hline 24-Nov & $41 \mathrm{c}$ & $3569 a$ & $9045 a$ \\
\hline 10-Dec & $37 d$ & $2788 b$ & $6878 b$ \\
\hline 26-Dec & $31 \mathrm{e}$ & $2243 b$ & $5512 b$ \\
\hline 10-Jan & $22 f$ & $1065 \mathrm{c}$ & $3200 \mathrm{c}$ \\
\hline LSD value & 0.94 & 849.55 & 1825.24 \\
\hline \multicolumn{4}{|c|}{ Priming (P) } \\
\hline Dry seed & $36 \mathrm{~b}$ & $2779 \mathrm{~b}$ & $6983 b$ \\
\hline Water soaked seed & $37 \mathrm{a}$ & $3116 a$ & $7630 a$ \\
\hline LSD value & 0.54 & 134.55 & 309.04 \\
\hline \multicolumn{4}{|c|}{ LSD values for interaction } \\
\hline SD x P & NS & NS & NS \\
\hline
\end{tabular}

Means with different letters differ significantly according to Least Significant Difference (LSD) test $(P<0.05)$. NS stands for non-significant difference

\section{Conclusion}

It is concluded from the results that optimum sowing date ( $29^{\text {th }}$ Oct to $10^{\text {th }}$ Nov) significantly increased yield and yield related components of wheat. Similarly seed priming with water for at least six hours enhanced growth and yield of late sown wheat.

\section{Authors' contributions}

Conceived and designed the experiments: $S$ Anwar \& $M$ Amin, Performed the experiments: $M$ Amin \& $S$ Anwar, Contributed reagents/materials/analysis tools: S Anwar, B Saeed \& M Islam, Analyzed the data: B Saeed, M Islam \& S 
Khan, Wrote the paper: M Islam \& S Anwar.

\section{References}

1. Waraich SA, Yasmin S \& Ashraf $S$ (1982). Genetics parameters influenced by seeding date in wheat (Triticum aestivum L.). Pak J Agri Res 3(4): 273-276.

2. Ahmad S, Muhammad A \& Hameedullah (1998). Wheat seed presoaking for improved germination. J of Agron \& Crop Sci 2: 125-127.

3. Akmal M, Shah SM, Asim M \& Arif M. 2011. Causes of yield reduction by delayed planting of hexaploid wheat in Pakistan. Pak J Bot 43(5): 2561-2568.

4. MINFAL (2015). Ministry of Food and Agriculture. Agricultural Statistics of Pakistan 2015-2016. Government of Pakistan, Islamabad.

5. Asgedom H \& Becker M (2001). Effect of seed priming with nutrient solutions on germination, seedling growth and weed competitiveness of cereals in Eritrea. In: Proc. Deutscher Tropentag 2001, Univ. Bonn and ATSAF, Margraf Publishers Press, Weickersheim 282.

6. Bari A (2003). Organic and inorganic nitrogen management for wheat and its residual effect on subsequent maize. Ph.D. Thesis. Department of agronomy, faculty of crop production sciences. NWFP Agricultural University Peshawar.

7. Witt MD (1996). Delayed planting opportunities with winter wheat in the central great planes. J Prod Agric 9: 74-78.

8. Arif M, Waqas M, Nawab K \& Shahid M (2007). Effect of seed priming in $\mathrm{Zn}$ solution on chickpea and wheat. African Crop Sci Con Pro 8: 237-240.

9. Bray CM, Davison PA, Ashraf M \& Taylor RM (1989). Biochemical events during osmopriming of leek seed. Ann Appl Biol 102: 185-193.

10. Coventry DR, Reeves JG, Brooke HD \& Cann DK (1993). Influence of genotype, sowing date and seeding rate on wheat development and yield. Aus $J$ Exp Agric 41(6): 751-757.

11. Dokuyucu T, Akkaya A \& Yigitoglu D (2004). The effect of different sowing dates on growing periods, yield and yield components of some bread wheat (Triticum aestivum L.) Cultivars grown in the East-Mediterranean region of Turkey. Agron J 103: 126-130.

12. Farooq M, Basra SMA, Rehman H \& Saleem BA (2008). Seed Priming Enhances the Performance of Late Sown Wheat (Triticum aestivum L.) By Improving Chilling Tolerance. J Agron \& Crop Sci 0931-2250.

13. Ghazi N (1998). Response of wheat and barley during germination to seed osmopriming at different water potential. J Agron \& Crop Sci 4: 229235.

14. Hamid M, Ashraf MY, Rehman KU \& Arashad M (2008). Influence of salicylic acid seed priming on growth and some biochemical attributes in wheat grown under saline conditions. Pak J Bot 40(1): 361-367.

15. Steel RGD \& Torrie JH. 1984. Principles and procedure of statistics $2^{\text {nd }}$ ed. Mc, Graw Hill, New York.

16. Hossain M \& Maniruzzaman AFM (1993). Effect of direct seeding and late season transplanting on wheat. Bangla J Agric Res 15: 6-10.

17. Iqbal $M$ \& Ashraf $M$ (2006). Wheat seed priming in relation to salt tolerance: growth, yield and levels of free salicylic acid and polyamines. Ann Bot Fennici 43 (4): 250-259.

18. Khan S \& Khalil SK. 2007. Effect of seed priming with phosphorous concentration and applications rates on wheat. M.Sc (Hons) thesis, Dept. of Agronomy, NWFP Agricultural University Peshawar.

19. Khakwani AA, Dennett MD \& Munir $M$ (2011). Early growth response of six wheat varieties under artificial osmotic stress condition. Pak J Agri Sci 48: 121-126. 
20. Khalil SK, Khan S, Rahman A, Khan AZ, Khalil IH, Amanullah, Wahab S, Mohammad F, Nigar S, Zubair M, Parveen S \& Khan A (2010). Seed priming and phosphorus application enhance phenology and dry matter production of wheat. Pak J Bot 42(3): 1849-1856.

21. Khan A, Khalil SK, Khan S \& Afzal A (2005). Priming affects crop stand of mung bean. Sarhad J Agric 21: 535538.

22. Surendra S, Matzen R, Pedersen TT \& Singh $S$ (1986). The effect of seed rate and row spacing on growth, yield and yield component of wheat. Indian $J$ Agron 30(1): 55-58.

23. Malik AU, Alias MA, Bukhsh HA \& Hussain I (2009). Effect of seed rate sown on different dates on wheat under agro-ecological conditions of Dera Ghazi Khan. J Ani Pl Sci 19(3): 126129.

24. Harris D, Pathan AK, Gothkar P, Joshi A, Chivasa W \& Nyamudeza P (2001).
On-farm seed priming: using participatory methods to revive and refine a key technology. Agric Sys 69: 151-164.

25. Razzaq A, Khanzada \& Shah P (1986). Effect of sowing dates and varieties on yield and yield components of wheat in the Peshawar valley. Sarhad J Agri 2(1): 29-38.

26. Wiese MV (1987). Compendium of Wheat Diseases. APS Press, St. Paul, MN 112.

27. Aguilar-Mriscal I \& Hunt LA (1991). Grain yield and spike number in winter wheat in humid continental climate. Crop Sci 31: 360-362.

28. Rowse HR (1995). Drum priming a non-osmotic method of priming seeds. Seed Sci Tec 24: 281-294.

29. Basra SMA, Pannu IA \& Afzal I (2003). Evaluation of seedling vigor of hydro and matriprimed wheat (Triticum aestivum L.) seeds. Int $J$ Agric \& Bio 5(2): 121-123. 